\title{
Clinical Profile and Outcome of Critically Ill Patients with Tuberculosis
}

\author{
Lovely Thomas ${ }^{1}$, Binila Chacko², Samuel Jupudi ${ }^{3}$, Alice Mathuram ${ }^{4}$, Tina George ${ }^{5}$, Karthik Gunasekaran ${ }^{6}$, Sudha J Rajan ${ }^{7}$, \\ Ronald AB Carey ${ }^{8}$, John V Peter ${ }^{9}$
}

\begin{abstract}
Aim and objective: Although studies have described the clinical profile of patients admitted to the intensive care unit (ICU) with tuberculosis, it is unclear if the type of tuberculosis (pulmonary, extrapulmonary, or disseminated) impacts outcome.

Matrials and methods: Demographic data, microbiology, treatment, and outcomes over 5 years (2012-16) were obtained from electronic records. Patients were categorized as pulmonary, extrapulmonary, or disseminated tuberculosis. Comparisons were done using $t$ test and Fisher's exact test as appropriate. Predictors of outcome were explored using bivariate and multivariate logistic regression analysis and expressed as odds ratio (OR) with $95 \%$ confidence intervals $(\mathrm{Cl})$.

Results: Of the 428 ICU admissions with suspected tuberculosis, 212 (121 male) patients with mean (standard deviation) age of 41.9 (16.7) years and APACHE-II score of $20.8(6.6)$ were diagnosed as pulmonary $(n=55)$ and extrapulmonary $(n=52)$ or disseminated tuberculosis $(n=$ 105). In 50.5\%, the diagnosis of tuberculosis was established during the current ICU admission when they presented with organ dysfunction. Overall, microbiological confirmation was possible in $75.5 \%$; $14(10.3 \%)$ isolates were Rifampicin resistant. ICU admission was required primarily for ventilation $(n=176 ; 83 \%)$ and hemodynamic instability $(n=67 ; 32 \%)$. Hospital mortality was $50 \%$. Outcomes were similar in the three groups except for longer duration of stay $(p$ value $=0.04)$ in disseminated tuberculosis. On multivariate logistic regression analysis, pulmonary tuberculosis (OR 2.83; 95\% Cl 1.15-6.95) and vasoactive treatment (OR 15.8; 95\% Cl 6.4-39.2) were independently associated with death; need for ventilation predicted mortality perfectly.

Conclusion: In this cohort of patients admitted to ICU with tuberculosis, 50\% were newly diagnosed during ICU admission. Pulmonary site of involvement and need for organ support are independent risk factors for death.

Keywords: Critically ill patients, Gene Xpert, Mortality, Tuberculosis.

Indian Journal of Critical Care Medicine (2021): 10.5005/jp-journals-10071-23503
\end{abstract}

\section{INTRODUCTION}

Tuberculosis (TB) remains a major public health problem, particularly in low- and middle-income countries. India accounts for the highest incidence of TB, including multi-drug resistant TB and features among the top countries of TB associated with human immunodeficiency virus (HIV) infection. Despite curative therapy, TB is the leading cause of infectious disease deaths, ${ }^{1}$ with almost 2 million deaths annually.

There is limited information on the outcome of TB patients who require intensive care unit (ICU) management. There are studies ${ }^{2-19}$ that have profiled patients with TB and evaluated for factors associated with poor outcomes. In these studies, mortality ranged from $21.6 \%{ }^{7}$ in developed countries to $81 \%^{20}$ in those requiring mechanical ventilation. High APACHE-II score, severe respiratory failure, coinfection with HIV, and multi-organ failure were some factors associated with unfavorable outcome. . $^{3,6,9}$ In developing countries, delayed diagnosis and drug resistance may additionally contribute to poor outcome. Majority of these studies looked at critically ill patients with pulmonary TB. ${ }^{12-16,18,19}$ It is unclear whether the type of TB impacts outcomes, as studies have suggested that pulmonary $\mathrm{TB}^{4}$ and miliary $\mathrm{TB}^{8}$ are associated with poor outcome.

This study was undertaken to describe the characteristics of adult critically ill patients with TB and to identify factors that predict mortality. We also assessed if outcomes of critically ill patients with

\author{
1-3,9 Department of Medical Intensive Care Unit, Christian Medical \\ College and Hospital, Vellore, Tamil Nadu, India \\ ${ }^{4}$ Department of Medicine 1, Christian Medical College and Hospital, \\ Vellore, Tamil Nadu, India \\ ${ }^{5}$ Department of Medicine 2, Christian Medical College and Hospital, \\ Vellore, Tamil Nadu, India \\ ${ }^{6}$ Department of Medicine 5, Christian Medical College and Hospital, \\ Vellore, Tamil Nadu, India \\ ${ }^{7}$ Department of Medicine 3, Christian Medical College and Hospital, \\ Vellore, Tamil Nadu, India \\ ${ }^{8}$ Department of Medicine 4, Christian Medical College and Hospital, \\ Vellore, Tamil Nadu, India
}

Corresponding Author: Binila Chacko, Department of Medical Intensive Care Unit, Christian Medical College and Hospital, Vellore, Tamil Nadu, India, Phone: +919600272412, e-mail: binilachacko@ gmail.com

How to cite this article: Thomas L, Chacko B, Jupudi S, Mathuram A, George T, Gunasekaran K, et al. Clinical Profile and Outcome of Critically III Patients with Tuberculosis. Indian J Crit Care Med 2021;25(1): 21-28.

Source of support: Nil

Conflict of interest: None

() The Author(s). 2021 Open Access This article is distributed under the terms of the Creative Commons Attribution 4.0 International License (https://creativecommons. org/licenses/by-nc/4.0/), which permits unrestricted use, distribution, and non-commercial reproduction in any medium, provided you give appropriate credit to the original author(s) and the source, provide a link to the Creative Commons license, and indicate if changes were made. The Creative Commons Public Domain Dedication waiver (http://creativecommons.org/publicdomain/zero/1.0/) applies to the data made available in this article, unless otherwise stated. 
extrapulmonary and disseminated TB were different from those diagnosed to have pulmonary TB.

\section{Materials and Methods}

In this retrospective study spanning 5 years (2012-2016), demographic, clinical, microbiological treatment and outcome data of adult critically ill patients with TB were abstracted from electronic hospital records to data abstraction forms. These patients were admitted in a 24-bed medical critical care unit in a 2,500-bed, university-affiliated, private teaching hospital in semi-urban India. Patients were categorized into three groups: pulmonary, extrapulmonary, and disseminated TB.

Pulmonary TB was diagnosed if confirmed bacteriologically (positive smear, culture or by rapid diagnostic tests such as Gene Xpert) from biological specimens from the lung parenchyma or tracheobronchial tree or if clinically diagnosed by a medical practitioner who decided to treat the patient with antitubercular treatment (ATT) based on radiological findings even in the absence of laboratory confirmation. ${ }^{21}$ Patients with pulmonary TB and pleural involvement were classified as pulmonary TB. ${ }^{21}$

"Bacteriologically confirmed or clinically diagnosed case of TB involving organs other than the lungs" (e.g., pleura, lymph nodes, abdomen, genitourinary tract, skin, joints and bones, meninges) was classified as extrapulmonary TB. ${ }^{22,23}$ Disseminated TB as described by Iseman included miliary tuberculosis (radiological or histological evidence), ${ }^{24}$ isolation of M. tuberculosis from blood, bone marrow or liver, or from specimens from 2 noncontiguous organs in a single patient.

Microbiological data that included smear, Gene Xpert, mycobacteria growth indicator tube (MGIT), and acid-fast bacilli (AFB) culture were obtained. In the absence of microbiological confirmation of TB, initiation of ATT was considered empirical if a patient was started on ATT based on suggestive reports (either histopathological or fluid analysis) or negative reports and high clinician suspicion of TB.

The primary outcome of interest was hospital mortality. Secondary outcomes included ICU and hospital length of stay (LOS), ventilation duration, ventilator-free days (VFD), ${ }^{25}$ and hospitalacquired infections (HAI). Standard definitions were used for the diagnosis of ventilator-associated pneumonia (VAP), blood stream infection (BSI), and catheter-associated urinary tract infections (UTI). ${ }^{26,27}$ The need for organ support (respiratory, hemodynamic, and renal) was also documented.

Summary data were presented as mean with standard deviation (SD) for normally distributed data and as median with interquartile range (IQR) if data were skewed. Clinical features and outcomes were compared between pulmonary TB (reference group) and the other two groups (extrapulmonary, disseminated) using $t$ test and Fisher exact test as appropriate. Predictors of outcome were explored using bivariate and multivariate logistic regression analysis. For this analysis, pulmonary TB was compared to pooled data of extrapulmonary and disseminated TB. Variables were incorporated into the multivariate analysis if $p$ value was $<0.1$ on bivariate analysis. Results were reported as odds ratio (OR) with $95 \%$ confidence interval $(\mathrm{Cl})$. The study was approved by the Institutional Review Board (IRB) and the ethics committee of the institution (IRB Min No 10664 dated 19.4.2017).

\section{Results}

\section{Baseline Demographic Data}

During the study period, 7,796 patients were admitted to Medical ICU. Of the 428 admissions with suspected TB, 212 patients were diagnosed to have TB. This study cohort had a mean (SD) age of 41.9 (16.7) years. The mean (SD) APACHE-II score of 20.8 (6.6) suggested moderate-to-severe illness severity at admission. About half (50.4\%) the patients were newly diagnosed as TB during the current ICU admission. The remaining were diagnosed prior to ICU admission at a median (IQR) symptom duration of 13.5 (4-47) days and had received antitubercular treatment for the same duration. The most frequent comorbidities (Table 1) were diabetes mellitus (29.7\%), HIV coinfection (9.9\%), and chronic respiratory disorders (6.1\%).

\section{Indications for ICU Admission}

The major reasons for ICU admission were respiratory failure (83\%) and hemodynamic instability (31.6\%).

Ventilatory support was required either for lung-related causes $(n=114)$ or airway protection $(n=61)$. Among the lungrelated causes, acute respiratory distress syndrome (ARDS) $(n=$ 76), pneumonia ( $n=13)$, impending respiratory failure in patients with distributive shock $(n=14)$, and pulmonary edema $(n=7)$ were the major reasons for ventilatory assistance. Airway protection was required for neurological reasons in 59 patients of whom 34 had tuberculous meningitis, 6 patients had seizures, and the other 19 patients had low GCS due to other causes (septic encephalopathy, post-cardiac arrest, intracranial bleed, poisoning, or electrolyte abnormalities). Two patients required airway protection for nonneurological causes (stridor and GI bleed).

Although the predominant type of shock in these patients was warm shock, a small proportion (7.5\%) of patients with hemodynamic instability $(n=67)$ had cold shock (Table 1).

Although a majority of patients were admitted to ICU $(n=94)$ for primary problems related to TB (e.g., TB ARDS, severe parenchymal disease or TB meningitis), some patients required admission ( $n=$ 76) for TB-related complications, such as secondary bacterial sepsis, electrolyte abnormalities, hydrocephalus, etc. In about 20\% ( $n=$ 42) of admissions, patients on treatment for TB were admitted to the ICU for reasons unrelated to TB (e.g. acute coronary syndrome, pulmonary edema, post cardiac arrest, poisoning, gastrointestinal bleed and diabetic ketoacidosis).

\section{Categorization of Patients}

Fifty-five patients were diagnosed as pulmonary, while extrapulmonary TB was diagnosed in 52 patients and disseminated TB in 105 patients. TB meningitis $(n=33)$ and isolation of TB from 2 noncontiguous sites $(n=88)$ were the most frequent presentation of extrapulmonary TB and disseminated TB, respectively. Only 11 patients presented with a clinical picture consistent with miliary TB.

There were no significant differences in the 3 groups with respect to age, gender, illness severity, duration of TB, and whether they were newly diagnosed TB or not (Table 1). When compared to pulmonary TB, a significantly higher proportion of patients with extrapulmonary TB required ventilatory support for airway protection rather than lung related causes.

More patients with pulmonary TB were admitted to ICU with processes that were directly related to the disease (TB) per se when compared to extrapulmonary TB ( $p$ value $<0.001$ ) or disseminated 
Table 1: Demographic data

\begin{tabular}{|c|c|c|c|c|c|c|}
\hline Variable & Overall $(n=212)$ & Pulmonary $(n=55)$ & $\begin{array}{l}\text { Extrapulmonary } \\
(n=52)\end{array}$ & pvalue & $\begin{array}{l}\text { Disseminated } \\
(n=105)\end{array}$ & $p$ value \\
\hline Age; Mean (SD) years & $41.9(16.7)$ & $44.5(16.9)$ & $42.1(17.3)$ & 0.24 & $40.5(16.2)$ & 0.08 \\
\hline Male:Female & 121:91 & $31: 24$ & $25: 27$ & 0.44 & $65: 40$ & 0.5 \\
\hline APACHE II*; Mean (SD) & $20.8(6.6)$ & $21.0(6.6)$ & $21.5(7.4)$ & 0.63 & $20.4(6.3)$ & 0.3 \\
\hline Newly diagnosed TB & $107(50.5)$ & $26(47.3)$ & $20(38.5)$ & 0.44 & $61(58.1)$ & 0.24 \\
\hline TB treatment duration ${ }^{\ddagger}$ & $13.5(4-47)$ & $12(6-60)$ & $14(4-46)$ & 0.74 & $13.5(3-47)$ & 0.91 \\
\hline \multicolumn{7}{|l|}{ Reason for ICU admission } \\
\hline Primary TB related processes & $94(44.3)$ & $30(54.5)$ & $18(34.6)$ & & $46(43.8)$ & \\
\hline Secondary TB related complications & $76(35.8)$ & $10(18.2)$ & $29(55.8)$ & $<0.001$ & $39(37.1)$ & $<0.04$ \\
\hline Sepsis & 26 & 4 & 7 & & 15 & \\
\hline Hydrocephalus & 28 & 0 & 17 & & 11 & \\
\hline Bacterial pneumonia & 11 & 3 & 2 & & 6 & \\
\hline TB sequelae related complications & 1 & 1 & 0 & & 0 & \\
\hline Immune reconstitution & 1 & 1 & 0 & & 3 & \\
\hline Pneumothorax/pneumomediastinum & 1 & 1 & 1 & & 4 & \\
\hline Hyponatremia & 3 & 0 & 0 & & 3 & \\
\hline Seizures & 5 & 0 & 1 & & 4 & \\
\hline Non TB related admission ${ }^{\dagger}$ & $42(19.8)$ & $15(27.3)$ & $5(9.6)$ & & $20(19.0)$ & \\
\hline Ventilatory support & $176(83)$ & $47(85.4)$ & $45(86.5)$ & 1 & $84(80)$ & 0.52 \\
\hline Lung related causes & $114(64.8)$ & $37(78.7)$ & $17(37.8)$ & $<0.001$ & $60(71.4)$ & 0.41 \\
\hline Airway protection & $62(35.2)$ & $10(21.3)$ & $28(62.2)$ & $<0.001$ & $24(28.6)$ & 0.41 \\
\hline Hemodynamic support & 67 (31.6) & $20(36.3)$ & $10(19.2)$ & & $37(35.2)$ & \\
\hline Warm shock & $62(92.5)$ & $19(95)$ & $10(100)$ & 0.06 & $33(89.2)$ & 1 \\
\hline Cold shock & $5(7.5)$ & $1(5)$ & $0(0)$ & & $4(10.8)$ & \\
\hline \multicolumn{7}{|l|}{ Comorbid illnesses } \\
\hline Diabetes & $63(29.7)$ & $20(36.4)$ & $17(30.8)$ & 0.68 & $27(25.7)$ & 0.2 \\
\hline Respiratory disorders $^{\dagger \dagger}$ & $13(6.1)$ & $8(14.6)$ & $1(1.9)$ & 0.03 & $4(3.8)$ & 0.02 \\
\hline IHD & $7(3.3)$ & $2(3.6)$ & $2(3.9)$ & 1 & $3(2.9)$ & 1 \\
\hline Autoimmune disease & $8(3.8)$ & $3(5.5)$ & $2(3.9)$ & 1 & $3(2.9)$ & 0.41 \\
\hline Immunosuppressive & $10(4.7)$ & $4(7.3)$ & $2(3.9)$ & 0.68 & $4(3.8)$ & 0.45 \\
\hline $\mathrm{HIV}^{\neq \neq}$ & $21(9.9)$ & $4(7.3)$ & $3(5.8)$ & 1 & $14(13.3)$ & 0.3 \\
\hline Steroids & $7(3.3)$ & $3(5.5)$ & $2(3.9)$ & 1 & $2(1.9)$ & 0.34 \\
\hline Alcohol & $21(9.9)$ & $7(12.7)$ & $4(7.7)$ & 0.53 & $10(9.5)$ & 0.59 \\
\hline
\end{tabular}

Values expressed are number of patients and percentages (\%) unless specified; SD, standard deviation; TB, tuberculosis; APACHE, acute physiology and chronic health evaluation; HIV, human immunodeficiency virus; IHD, ischemic heart disease; IQR, interquartile range

${ }^{*}$ APACHE II data available only for 181 patients

${ }^{\dagger}$ Reasons for admission were unrelated to TB and included acute coronary syndrome, pulmonary edema, post cardiac arrest, poisoning, gastrointestinal bleed and diabetic ketoacidosis

${ }^{+t}$ Includes asthma, COPD and other illnesses

${ }^{\ddagger}$ Duration of TB treatment in those who were diagnosed as TB prior to ICU admission expressed as median IQR

${ }^{\ddagger}$ Of the 21 patients with HIV, 7 were on antiretroviral therapy

TB ( $p$ value $<0.04)$, where complications as a result of the disease or treatment or other medical problems unrelated to TB in patients on treatment for TB were the more frequent reasons for ICU admission (Table 1).

\section{Microbiological and Histopathological Data}

While 210 of the 212 patients had some form of microbiological TB testing, there was microbiological confirmation in only $3 / 4$ th of the patients (Table 2). Overall, $72.7 \%$ of samples were tested positive by Gene Xpert in contrast to a positivity rate of $49.6 \%$ by MGIT and $30.4 \%$ by routine AFB cultures; gene Xpert positivity was $90 \%$, $82.2 \%$, and $34.2 \%$ in pulmonary, disseminated, and extrapulmonary TB, respectively. Of the 136 samples where rifampicin sensitivity could be assessed, 122 (89.7\%) were susceptible. Of the rifampicinresistant TB $(n=14), 6$ had disseminated TB, while 4 patients each had pulmonary and extrapulmonary TB.

Of the 96 tissues tested, 47 (49\%) had definitive histopathological evidence of tuberculosis and 24 (25\%) had histopathology was suggestive of TB. Histopathology was the sole means of definitive TB diagnosis (microbiology negative) in only one patient in the entire cohort.

\section{Treatment Details}

Empiric ATT was started in 52 (24.5\%) patients. Among these, treatment was initiated based on investigations suggestive of TB in 41 patients, either by fluid analysis alone $(n=40)$ or by histopathology 
Tuberculosis in the Critically Ill

Table 2: Microbiological data

\begin{tabular}{llllll}
\hline Test $N(\%)$ & Overall $(n=212)$ & $\begin{array}{l}\text { Pulmonary TB } \\
(n=55)\end{array}$ & $\begin{array}{l}\text { Extrapulmonary } \\
(n=52)\end{array}$ & $p$ value & $\begin{array}{l}\text { Disseminated TB } \\
(n=105)\end{array}$ \\
\hline Positive AFB smear & $70 / 142(49.3)$ & $38 / 45(84.4)$ & $0 / 22(0)$ & $<0.001$ & $32 / 75(42.7)$ \\
Gene Xpert positive & $125 / 172(72.7)$ & $37 / 41(90.2)$ & $14 / 41(34.2)$ & $<0.001$ & $74 / 90(82.2)$ \\
Rifampicin susceptible & $122 / 136(89.7)$ & $36 / 40(90)$ & $10 / 14(71.4)$ & 0.18 & $76 / 82(92.7)$ \\
MGIT & $68 / 137(49.6)$ & $16 / 27(59.3)$ & $9 / 32(28.1)$ & 0.41 & $43 / 78(55.1)$ \\
AFB culture & $34 / 112(30.4)$ & $12 / 25(48)$ & $2 / 30(6.7)$ & $<0.001$ & $20 / 57(35.1)$ \\
Histopathology* & & & & 0.3 & 0.26 \\
$\quad$ Definitive TB & $47 / 96(48.9)$ & $1 / 6(16.7)$ & $4 / 17(23.5)$ & 0.34 & $42 / 73(57.5)$ \\
$\quad$ Suggestive of TB & $24 / 96(25.0)$ & $0 / 6(0)$ & $4 / 17(23.5)$ & & $20 / 73(27.4)$ \\
$\quad$ Negative & $25 / 96(26.0)$ & $5 / 6(83.3)$ & $9 / 17(53.0)$ & & $11 / 73(15.1)$ \\
Empiric treatment & $52(24.5)$ & $4(7.3)$ & $35(67.3)$ & $<0.001$ & $13(12.4)$ \\
\hline
\end{tabular}

All values expressed are total number of patients positive for the test out of the number tests; values in parenthesis indicate percentages unless specified; MGIT, mycobacteria growth indicator tube; AFB, acid fast bacillus; TB, tuberculosis

*Histopathology done in 96 patients-results categorized as definitive, suggestive and negative

Table 3: Treatment and outcomes

\begin{tabular}{|c|c|c|c|c|c|c|}
\hline & Overall $(n=212)$ & $\begin{array}{l}\text { Pulmonary TB } \\
(n=55)\end{array}$ & $\begin{array}{l}\text { Extrapulmonary } \\
(n=52)\end{array}$ & $p$ value & $\begin{array}{l}\text { Disseminated TB } \\
(n=105)\end{array}$ & $p$ value \\
\hline \multicolumn{7}{|l|}{ Treatment data $n(\%)$} \\
\hline Vasoactive support & $136(64.2)$ & $33(60)$ & $34(65.4)$ & 0.69 & $69(65.7)$ & 0.49 \\
\hline Dialysis & $23(10.9)$ & $3(5.5)$ & $5(9.6)$ & 0.48 & $15(14.3)$ & 0.12 \\
\hline Ventilation & $186(87.7)$ & 47 (85.5) & 49 (94.2) & 0.2 & $90(85.7)$ & 1 \\
\hline NIV & $40(18.9)$ & $16(29.1)$ & $6(11.5)$ & 0.03 & $18(17.1)$ & 0.1 \\
\hline Invasive & 169 (79.7) & $43(78.2)$ & $46(88.5)$ & 0.2 & $80(76.2)$ & 0.85 \\
\hline \multicolumn{7}{|l|}{ Outcome data $n(\%)$} \\
\hline Hospital mortality & $106(50)$ & $33(60)$ & $23(44.2)$ & 0.12 & $50(47.6)$ & 0.18 \\
\hline ICU LOS ${ }^{\dagger}$ & $6(4-11)$ & $5(3-10)$ & $6(4.5-12)$ & 0.19 & $7(4-11)$ & 0.29 \\
\hline Hospital LOS ${ }^{\dagger}$ & $15(8-24)$ & $12(6-21)$ & $16(10-23.5)$ & 0.15 & $15(8-28)$ & 0.04 \\
\hline Ventilation duration $^{\dagger}$ & $6(4-11)$ & $5(3-12)$ & $5(4-11)$ & 0.83 & $6(4-11)$ & 0.87 \\
\hline $\mathrm{VFD}^{\dagger}$ & $0(0-23)$ & $0(021)$ & $10.5(0-23)$ & 0.12 & $9(0-24)$ & 0.09 \\
\hline $\mathrm{HAl}$ & $50(23.6)$ & $8(14.6)$ & $16(30.8)$ & 0.06 & $26(24.8)$ & 0.16 \\
\hline VAP & $27(12.7)$ & $8(14.6)$ & $5(9.6)$ & 0.56 & $14(13.3)$ & 0.81 \\
\hline BSI & $26(12.3)$ & $3(5.5)$ & $9(17.3)$ & 0.07 & $14(13.3)$ & 0.18 \\
\hline UTI & $9(4.3)$ & 0 & $3(5.8)$ & 0.11 & $6(5.7)$ & 0.1 \\
\hline
\end{tabular}

Values expressed are number of patients and percentages (\%) unless specified; ICU, intensive care unit; LOS, length of stay; VFD, ventilation free days; HAI, hospital acquired infections; IQR, interquartile range; VAP, ventilator-associated pneumonia; BSI, bloodstream infection; UTI, urinary tract infection; VFD, ventilator free days

${ }^{\dagger}$ Median (IQR) range in days

alone $(n=1)$. Over $80 \%(n=33)$ of the patients diagnosed on fluid analysis alone were presumed to have tuberculous meningitis and showed response to antitubercular therapy. Among the patients who presented with pleural effusions, ICU admission was for either secondary sepsis or unrelated biventricular failure. One patient was admitted with intestinal obstruction.

There was no significant difference between the groups with respect to need for organ support (Table 3). In patients presenting with respiratory failure, when compared to extrapulmonary $\mathrm{TB}$, a significantly higher ( $p$ value $=0.03$ ) proportion of patients with pulmonary TB were managed with noninvasive ventilation (NIV).

\section{Outcomes}

Overall, ICU mortality was 42\% (89/212), and hospital mortality was $50 \%(106 / 212)$. While disseminated TB had significantly ( $p$ value $=0.02$ ) longer hospital LOS, all other outcomes were similar (Table 3).
On bivariate logistic regression analysis (Table 4), age, APACHE-II, male gender, pulmonary TB, vasoactive support, ventilation, and dialysis were found to be associated with mortality. On multivariate logistic regression analysis, pulmonary TB (OR 2.83; $95 \% \mathrm{Cl} 1.15-6.95$ ) and need for vasoactive treatment (OR 15.8; 95\% Cl 6.4-39.2) were independently associated with death. Need for ventilation was not incorporated into the multivariate analysis since this predicted mortality perfectly.

\section{Discussion}

This cohort of 212 TB patients were categorized as pulmonary TB $(n=55)$, extrapulmonary TB $(n=52)$, and disseminated TB $(n=105)$. Half of the patients ( $n=107 ; 50.4 \%$ ) were newly diagnosed as TB during the current ICU admission. Patients with disseminated TB had significantly ( $p$ value $=0.04$ ) longer duration of hospital stay 
Tuberculosis in the Critically Ill

Table 4: Factors associated with mortality

\begin{tabular}{|c|c|c|c|c|c|c|}
\hline \multirow[b]{2}{*}{ Factor } & \multicolumn{3}{|c|}{ Bivariate analysis } & \multicolumn{3}{|c|}{ Multivariate analysis } \\
\hline & OR & $95 \% \mathrm{Cl}$ & $p$ value & OR & $95 \% \mathrm{Cl}$ & $p$ value \\
\hline Age $^{*}$ & 1.02 & $1.0-1.03$ & 0.05 & 1.0 & $0.98-1.02$ & 1.0 \\
\hline APACHE II* & 1.11 & $1.06-1.17$ & $<0.001$ & 1.06 & $1.1-13$ & 0.09 \\
\hline Gender* (male) & 1.65 & $0.96-2.86$ & 0.07 & 2.16 & $0.99-4.70$ & 0.053 \\
\hline Pulmonary site* & 1.73 & $0.93-3.22$ & 0.09 & 2.83 & $1.15-6.95$ & 0.02 \\
\hline Vasoactive support* & 9.3 & $4.7-18.3$ & $<0.001$ & 15.8 & $6.4-39.2$ & $<0.001$ \\
\hline Ventilation & 15.2 & $3.5-66.3$ & $<0.001$ & & & \\
\hline Dialysis* & 5.6 & $1.83-17$ & $<0.003$ & 3.63 & $0.87-15.1$ & 0.08 \\
\hline Ventilation duration & 0.97 & $0.93-1.02$ & 0.23 & & & \\
\hline VFD & 1.03 & $0.98-1.08$ & 0.32 & & & \\
\hline $\mathrm{HAl}$ & 1.37 & $0.72-2.6$ & 0.33 & & & \\
\hline
\end{tabular}

VFD, ventilation-free days; $\mathrm{HAl}$, hospital acquired infections; APACHE, acute physiology and chronic health evaluation; VFD, ventilator-free days; $\mathrm{OR}$, odds ratio; $\mathrm{Cl}$, confidence interval

*Variables incorporated in the multivariate analysis (if $p<0.1$ on bivariate logistic regression analysis); Ventilation was not incorporated in the multivariate logistic model as need for ventilation predicted failure perfectly; pulmonary site was compared with non-pulmonary sites (which included extrapulmonary and disseminated tuberculosis)

than those admitted with pulmonary TB. Hospital mortality was $50 \%$. Pulmonary site of TB and need for ventilation and vasoactive treatment were independent predictors of death.

The acute presentation of TB, with moderate to severe illness severity and a high proportion requiring respiratory (83\%) and hemodynamic (31.6\%) support in our cohort, highlights the importance of considering TB in the differential diagnosis of patients admitted to the ICU with organ dysfunction. A recent study noted that tuberculosis may have a shorter incubation period than generally considered. ${ }^{28}$ It is possible that the nonspecific nature of symptoms, particularly in extrapulmonary and disseminated TB coupled with its protean manifestations, may have delayed diagnosis and resulted in more acute presentations in the $50 \%$ of patients in who TB was diagnosed during the current ICU admission. It was also evident from our study that the reasons for ICU admission were not only due to TB perse (e.g. ARDS, TB meningitis) but also due to complications of TB or its treatment or other medical problems unrelated to TB (Table 1). It is thus important for clinicians to be aware that nontuberculous processes in a patient with TB may necessitate ICU admission (Table 5).

Overall, microbiological diagnosis was possible in $75 \%$ of the patients. As a diagnostic tool, Gene Xpert performed better when compared to MGIT and AFB cultures, more so in disseminated tuberculosis where the diagnosis can be challenging. It was interesting to note that the performance of the rapid diagnostic test (Gene Xpert) was consistent with the published literature. ${ }^{29}$ Rifampicin resistance was seen in $10.3 \%$ of the isolates. This was higher than that reported (3.8\%) by Valade et al. ${ }^{8}$

While the overall hospital mortality of patients admitted to ICU with TB appears to be high (50\%), it was comparable to other published studies ${ }^{2,4-6,8,10,30}$ with similar illness severity (APACHE-II 18-22.8), where the mortality ranged from $53.8-65.7 \%$ (Table 6). Organ failure ${ }^{4,8-10}$ and severity of illness $s^{3-7,10,11}$ were predictors of an unfavorable outcome in most studies. Our study is thus consistent with the published literature of organ failure contributing to death in TB patients admitted to the ICU. In contrast, APACHE-II score was not independently associated with death in our study.

The current study found that pulmonary site of TB and need for ventilation and vasoactive treatment were independent predictors of death. This is consistent with a retrospective study of 39 patients
Table 5: Processes in tuberculosis that may require intensive care admission and management

\begin{tabular}{|c|c|c|}
\hline Site & Primary process & Secondary process* \\
\hline \multirow[t]{5}{*}{ Parenchymal lung } & Fibrocavitary disease & Bacterial infection \\
\hline & Miliary TB & $\begin{array}{l}\text { Fungal (e.g., } \\
\text { aspergillosis) infection }\end{array}$ \\
\hline & Tuberculous ARDS & TB sequel (e.g., fibrosis) \\
\hline & $\begin{array}{l}\text { TB } \\
\text { bronchopneumonia }\end{array}$ & Immune reconstitution \\
\hline & & $\begin{array}{l}\text { Hemoptysis } \\
\text { (Rasmussen aneurysm) }\end{array}$ \\
\hline \multirow[t]{2}{*}{ Pleural disease } & TB pleural effusion & Pneumothorax \\
\hline & TB empyema & \\
\hline \multirow[t]{4}{*}{$\begin{array}{l}\text { Central nervous } \\
\text { system }\end{array}$} & TB meningitis & $\begin{array}{l}\text { Noncommunicating } \\
\text { hydrocephalus }\end{array}$ \\
\hline & $\begin{array}{l}\text { Basal arachnoiditis } \\
\text { due to TB }\end{array}$ & Seizures \\
\hline & Tuberculoma & $\begin{array}{l}\text { Electrolyte } \\
\text { abnormalities }\end{array}$ \\
\hline & TB brain abscess & \\
\hline \multirow{2}{*}{$\begin{array}{l}\text { Abdominal } \\
\text { tuberculosis }\end{array}$} & Massive ascites & Secondary sepsis \\
\hline & Intestinal obstruction & \\
\hline \multirow[t]{2}{*}{$\begin{array}{l}\text { Pericardial } \\
\text { tuberculosis }\end{array}$} & $\begin{array}{l}\text { Pericardial } \\
\text { tamponade }\end{array}$ & $\begin{array}{l}\text { Organ dysfunction } \\
\text { secondary to heart }\end{array}$ \\
\hline & $\begin{array}{l}\text { Constrictive } \\
\text { pericarditis }\end{array}$ & failure \\
\hline \multirow{2}{*}{$\begin{array}{l}\text { Musculoskeletal } \\
\text { tuberculosis }\end{array}$} & Psoas abscess & Paraplegia \\
\hline & & $\begin{array}{l}\text { Superimposed } \\
\text { bacterial infection }\end{array}$ \\
\hline $\begin{array}{l}\text { TB } \\
\text { lymphadenopathy }\end{array}$ & Airway obstruction & \\
\hline \multirow[t]{2}{*}{ Disseminated TB } & $\begin{array}{l}\text { Multi-organ } \\
\text { dysfunction }\end{array}$ & Secondary sepsis \\
\hline & Hypotension $^{\dagger}$ & \\
\hline
\end{tabular}

*In addition patients on treatment for tuberculosis (TB) may present with drug toxicity due to antitubercular drugs, intercurrent infections, cardiac or neurological events unrelated to the primary TB process

${ }^{\dagger}$ Related to adrenal involvement 
Tuberculosis in the Critically Ill

Table 6: Studies exploring factors associated with mortality in critically ill tuberculosis (TB) patients requiring intensive care

\begin{tabular}{|c|c|c|c|c|c|c|c|c|}
\hline \multirow[b]{2}{*}{ No } & \multirow[b]{2}{*}{ Study/country } & \multirow[b]{2}{*}{ Year } & \multirow[b]{2}{*}{ Data } & \multirow[b]{2}{*}{ Sample size } & \multirow{2}{*}{$\begin{array}{l}\text { Disease } \\
\text { severity }\end{array}$} & \multicolumn{2}{|c|}{ Mortality } & \multirow{2}{*}{$\begin{array}{l}\text { Factors associated with } \\
\text { mortality }\end{array}$} \\
\hline & & & & & & $\operatorname{ICU}(\%)$ & Hospital (\%) & \\
\hline \multicolumn{9}{|c|}{ Retrospective studies } \\
\hline 1 & Current study (India) & 2019 & 5 years & 212 & $20.8(6.6)$ & 42 & 50 & $\begin{array}{l}\text { Pulmonary TB, need for } \\
\text { ventilation, vasoactive agents }\end{array}$ \\
\hline 2 & Muthu et al. (India) $)^{3}$ & 2018 & 16 years & 63 & $16.1(7.2)$ & NA & 44.4 & APACHE II, delta SOFA \\
\hline 3 & $\begin{array}{l}\text { Duro et al. (Portu- } \\
\text { gal) }\end{array}$ & 2017 & 7 years & 39 & $26(15.8)$ & 38.5 & 53.8 & $\begin{array}{l}\text { Smoking, age, sepsis/septic } \\
\text { shock, SAPS II/APACHE II, } \\
\text { positive respiratory samples, } \\
\text { MV, vasopressors }\end{array}$ \\
\hline 4 & $\begin{array}{l}\text { Loh et al. } \\
\text { (Singapore) }^{12}\end{array}$ & 2017 & 5 years & 75 & $22.6(7.3)$ & 48 & 62.7 & Low albumin on ICU admission \\
\hline 5 & $\begin{array}{l}\text { Bhurayanontachai } \\
\text { et al. (Thailand) }{ }^{13}\end{array}$ & 2016 & 10 years & 268 & $19.6(4)$ & NA & 54.5 & $\begin{array}{l}\text { Male, consolidation on chest } \\
\text { X-ray and low serum albumin }\end{array}$ \\
\hline 6 & Filiz et al. (Thaliand) ${ }^{5}$ & 2016 & 3 years & 35 & $18(7-32)$ & NA & 62.9 & $\begin{array}{l}\text { SOFA score, risk of mortality } \\
7.58 \text { times higher with MV }\end{array}$ \\
\hline 7 & Rollas et al. (Turkey) ${ }^{6}$ & 2015 & 6 years & 16 & $21.5(6-36)$ & 43.8 & NA & $\begin{array}{l}\text { Immunosuppression, } \\
\text { nosocomial infection, APACHE } \\
\text { II and SOFA scores, MV }\end{array}$ \\
\hline 8 & $\begin{array}{l}\text { Lanoix et al. } \\
\text { (France) }^{7}\end{array}$ & 2014 & 20 years & 97 & $4(0-17)^{\dagger}$ & 21.7 & 33 & SAPS II score \\
\hline 9 & 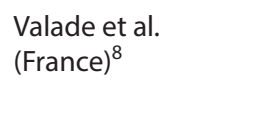 & 2012 & 10 years & 53 & $31(22-50)^{\dagger}$ & 38 & NA & $\begin{array}{l}\text { Miliary } \mathrm{TB}, \mathrm{MV} \text { and vasopressor } \\
\text { requirement on ICU } \\
\text { admission }\end{array}$ \\
\hline 10 & Lee et al. (Korea) ${ }^{14}$ & 2011 & 10 years & 67 & $21.3(8.1)$ & 58.2 & 61.2 & SOFA score \\
\hline 11 & Silva et al. (Brazil) $)^{2}$ & 2010 & 2 years & 67 & $22.8(6.8)$ & 56.7 & 65.7 & Early ICU admission, VAP \\
\hline 12 & Lin et al. ${ }^{11}$ (Taiwan) & 2009 & $\begin{array}{l}17 \\
\text { months }\end{array}$ & 59 & NA & NA & 67.8 & $\begin{array}{l}\text { Multiple organ failure syn- } \\
\text { drome, nosocomial pneumo- } \\
\text { nia }\end{array}$ \\
\hline 13 & Kim et al. (Korea) $)^{15}$ & 2008 & 18 years & 90 & $74.9(24)^{*}$ & NA & 65.6 & $\begin{array}{l}\text { Advanced age, Shock } \\
\text { unrelated to sepsis }\end{array}$ \\
\hline 14 & Ryu et al. $(\text { Korea })^{16}$ & 2007 & 10 years & 32 & $16(8-36)$ & NA & 59 & $\begin{array}{l}\text { Destroyed lungs, APCHE II> } \\
20, \mathrm{MV}\end{array}$ \\
\hline 15 & $\begin{array}{l}\text { Erbes et al. }{ }^{9} \\
\text { (Germany) }\end{array}$ & 2006 & 12 years & 58 & $13.1(5.6)$ & 22.4 & 25.9 & $\begin{array}{l}\text { Acute renal failure, MV, chronic } \\
\text { pancreatitis, sepsis, ARDS, } \\
\text { nosocomial pneumonia }\end{array}$ \\
\hline 16 & 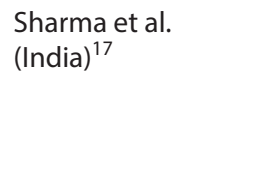 & 2006 & 23 years & 29 & $18.5(5.7)$ & NA & 41.4 & $\begin{array}{l}\text { APACHE II score }>18 ; \\
\text { APACHE II score }<18 \text { in the } \\
\text { presence of hyponatremia and } \\
\mathrm{PaO}_{2} / \mathrm{FIO}_{2} \text { ratio }<108.5 \text { in TB } \\
\text { ARDS }\end{array}$ \\
\hline 17 & Lee et al. (Taiwan) ${ }^{18}$ & 2003 & $5 y$ & 41 & $16.8(7.5)$ & 60.9 & 65.9 & $\begin{array}{l}\text { Multiple organ failure and } \\
\text { consolidation on chest } \\
\text { radiograph }\end{array}$ \\
\hline 18 & 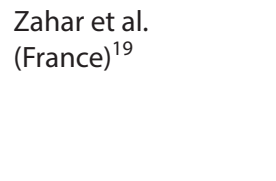 & 2001 & $8 y$ & 99 & & NA & $26.2^{* *}$ & $\begin{array}{l}\text { Time from symptom onset } \\
\text { to initiate treatment }>1 \\
\text { month, organ failures number, } \\
\text { serum albumin, extent of lung } \\
\text { involvement X-ray chest }\end{array}$ \\
\hline
\end{tabular}

Prospective studies

Balkema et al. (S Af- $2014 \quad 16 \mathrm{~m} \quad 83$ rica) ${ }^{10}$

$20.7(8.3) \quad 44.2 \quad 59.0$

APACHE II score, renal failure.

Year, year of publication; data represents data collection over years (y) or months ( $m$ ); ARDS, acute respiratory distress syndrome, MV, mechanical ventilation, VAP, ventilator associated pneumonia, APACHE II, acute physiology and chronic health evaluation, SOFA, sequential organ failure assessment score, IMV, invasive mechanical ventilation, SAPS, simplified acute physiology score, disease severity indicated by APACHE II unless specified as ${ }^{\dagger}$ Where it indicates SAPS II score, values in parenthesis are standard deviation (SD) or interquartile range (IQR); *APACHE III; **30-day mortality 
(66.7\% ventilated), where isolated pulmonary TB ( $n=28,71.8 \%)$ was associated with mortality. ${ }^{4}$ On the other hand, in a French study of 53 patients (51\% ventilated), Valade et al. ${ }^{8}$ reported that miliary pulmonary TB, which was observed in $25 \%$ of the patients and was predictive of fatality on multivariate analysis.

The discordant observations between the above two studies may be partly explained by the relatively small cohorts that reported multiple associations. Although the French study ${ }^{8}$ was consistent with our study in reporting an association between need for mechanical ventilation and vasopressor requirement and mortality, the association between miliary pulmonary TB and mortality contrasted our observations. On further study of the data from this study, ${ }^{8}$ only two patients had a non-pulmonary site of TB without pulmonary involvement. The remaining patients had pulmonary, pleural or mediastinal TB; $25 \%(n=13)$ were categorized as miliary TB and $53 \%(n=28)$ were classified as multi-lobar involvement. This could partly explain the difference between the French study and the current study.

The higher mortality risk in pulmonary TB when compared to extrapulmonary and disseminated TB is difficult to explain. It is possible that a relatively "hypoimmune" system ${ }^{24}$ in extrapulmonary and disseminated TB group combined with an immune reconstitution-like syndrome in patients with pulmonary TB could have contributed to the difference in outcome between these two types of presentations. However, this was not explored in the study.

The need for prolonged ICU stay and ventilation in patients with TB pre-disposes these patients to nosocomial infections. Although the incidence of HAl in this study was high (23.6\%), this did not contribute to mortality on logistic regression analysis. Three previous studies ${ }^{2,6,11}$ reported an association between nosocomial infection and death. In our study, extrapulmonary TB, when compared with pulmonary TB, had a trend ( $p$ value $=0.06$ ) to a higher incidence of HAI.

The study needs to be interpreted in the light of the following limitations. The study was retrospective; however, all data were available from the hospital and ICU electronic database. Despite the battery of tests available for diagnosis of TB in our institution, confirmation of diagnosis was possible only in about $75 \%$ of patients. In order to study the performance of the tests, it would have been ideal to analyze appropriate samples of all patients. Despite these limitations, this large study has systematically analyzed data and outcomes of critically ill TB patients with pulmonary, extrapulmonary or disseminated TB. This study also highlights that TB should be considered as a differential diagnosis in those presenting with organ dysfunction, since early diagnosis may result in improving outcomes.

\section{Conclusion}

Despite advances in the management of critically ill patients, those admitted with TB or diagnosed to have TB during intensive care admission continue to have a high mortality. Pulmonary site of involvement and need for organ support were associated with unfavorable outcomes. Early diagnosis through rapid diagnostic tests, appropriate supportive and specific therapy, and prevention of nosocomial infections would be key to improving outcomes in critically ill TB patients. Increasing awareness of tuberculosis presenting with organ dysfunction and prioritizing research in tackling this problem is the need of the hour.

\section{What This Study Adds}

- Tuberculosis can have acute presentation with multisystem organ damage.

- Pulmonary TB and requirement of organ support were associated with unfavorable outcomes.

- Reasons for ICU admission were not only due to TB per se (e.g. ARDS and TB meningitis) but also due to complications of TB or its treatment or other medical problems unrelated to TB.

- Gene expert can help in early diagnosis and performed better than other microbiological assays in all forms of TB.

\section{References}

1. Floyd K, Glaziou P, Zumla A, Raviglione M. The global tuberculosis epidemic and progress in care, prevention, and research: an overview in year 3 of the end TB era. The Lancet Respiratory Medicine 2018;6(4):299-314. DOI: 10.1016/S2213-2600(18)30057-2.

2. Silva DR, Menegotto DM, Schulz LF, Gazzana MB, Dalcin PT. Mortality among patients with tuberculosis requiring intensive care: a retrospective cohort study. BMC Infect Dis BioMed Central 2010;10(1):54. DOI: 10.1186/1471-2334-10-54.

3. Agarwal R, Behera D, Dhooria S, Prasad K, Sehgal IS, Muthu V, et al. Profile of patients with active tuberculosis admitted to a respiratory intensive care unit in a tertiary care center of North India. Indian J Crit Care Med 2018;22(2):63-66. DOI: 10.4103/ijccm.IJCCM_491_17.

4. Duro RP, Figueiredo Dias P, Ferreira AA, Xerinda SM, Lima Alves $C$, Sarmento AC, et al. Severe tuberculosis requiring intensive care: a descriptive analysis. Critical Care Research and Practice 2017;2017:9535463. DOI: 10.1155/2017/9535463.

5. Filiz KA, Levent D, Emel E, Pelin U, Turkay A, Aybüke K. Characteristics of active tuberculosis patients requiring intensive care monitoring and factors affecting mortality. Tuberc Respir Dis (Seoul) 2016;79(3):158164. DOI: 10.4046/trd.2016.79.3.158.

6. Rollas K, Kara A, Ortaç Ersoy NE, Özmen Süner K, Güllü MN, Öcal S, et al. Acute tuberculosis in the intensive care unit. Turk J Med Sci 2015;45(4):882-887. DOI: 10.3906/sag-1408-118.

7. Lanoix J-P, Gaudry S, Flicoteaux R, Ruimy R, Wolff M. Tuberculosis in the intensive care unit: a descriptive analysis in a low-burden country. Int J Tuberc Lung Dis 2014;18(5):581-587. DOI: 10.5588/ijtld.13.0901.

8. Valade S, Raskine L, Aout M, Malissin I, Brun P, Deye N, et al. Tuberculosis in the intensive care unit: a retrospective descriptive cohort study with determination of a predictive fatality score. Can J Infect Dis Med Microbiol 2012;23(4):173-178. DOI: 10.1155/2012/361292.

9. Erbes R, Oettel K, Raffenberg M, Mauch H, Schmidt-loanas M, Lode $\mathrm{H}$. Characteristics and outcome of patients with active pulmonary tuberculosis requiring intensive care. Eur Respir J 2006;27(6):12231228. DOI: 10.1183/09031936.06.00088105.

10. Balkema CA, Irusen EM, Taljaard JJ, Koegelenberg CFN. Tuberculosis in the intensive care unit: a prospective observational study. Int J Tuberc Lung Dis 2014;18(7):824-830. DOI: 10.5588/ijtld.13.0044.

11. Lin S-M, Wang T-Y, Liu W-T, Chang C-C, Lin H-C, Liu C-Y, et al. Predictive factors for mortality among non-HIV-infected patients with pulmonary tuberculosis and respiratory failure. Int J Tuberc Lung Dis 2009;13(3):335-340.

12. Loh WJ, Yu Y, Loo CM, Low SY. Factors associated with mortality among patients with active pulmonary tuberculosis requiring intensive care. Singapore Med J 2017;58(11):656-659. DOI: 10.11622/ smedj.2016160.

13. Bhurayanontachai $R$, Maneenil K. Factors influencing development and mortality of acute respiratory failure in hospitalized patient with active pulmonary tuberculosis: a 10-year retrospective review. J Thorac Dis 2016;8(7):1721-1730. DOI: 10.21037/jtd.2016.06.22.

14. Lee K, Kim JH, Lee JH, Lee W-Y, Park MS, Kim JY, et al. Acute respiratory distress syndrome caused by miliary tuberculosis: a multicentre survey in South Korea. Int J Tuberc Lung Dis 2011;15(8):1099-1103. DOI: $10.5588 / \mathrm{ijtld} .10 .0557$. 
15. Kim YJ, Pack KM, Jeong E, Na JO, Oh Y-M, Lee SD, et al. Pulmonary tuberculosis with acute respiratory failure. Eur Respir J 2008;32(6): 1625-1630. DOI: 10.1183/09031936.00070907.

16. Ryu YJ, Koh W-J, Kang EH, Suh GY, Chung MP, Kim H, et al. Prognostic factors in pulmonary tuberculosis requiring mechanical ventilation for acute respiratory failure. Respirol 2007;12(3):406-411. DOI: 10.1111/j.1440-1843.2006.01007.x.

17. Sharma SK, Mohan A, Banga A, Saha PK, Guntupalli KK. Predictors of development and outcome in patients with acute respiratory distress syndrome due to tuberculosis. Int J Tuberc Lung Dis 2006;10(4): 429-435.

18. Lee $\mathrm{PL}$, Jerng JS, Chang $\mathrm{YL}$, Chen $\mathrm{CF}$, Hsueh $\mathrm{PR}$, Yu CJ, et al. Patient mortality of active pulmonary tuberculosis requiring mechanical ventilation. Eur Respir J 2003;22(1):141-147. DOI: 10.1183/09031936.03.00038703.

19. Zahar JR, Azoulay E, Klement E, De Lassence A, Lucet JC, Regnier B, et al. Delayed treatment contributes to mortality in ICU patients with severe active pulmonary tuberculosis and acute respiratory failure. Intensive Care Med 2001;27(3):513-520. DOI: 10.1007/s001340000849.

20. Frame RN, Johnson MC, Eichenhorn MS, Bower GC, Popovich J. Active tuberculosis in the medical intensive care unit: a 15-year retrospective analysis. Crit Care Med 1987;15(11):1012-1014. DOI: 10.1097/00003246198711000-00005.

21. World Health Organization. Treatment of Tuberculosis. World Health Organization; 2010. p. 1.

22. Mbuh TP, Ane-Anyangwe I, Adeline W, Pokam BDT, Meriki HD, Mbacham WF. Bacteriologically confirmed extra pulmonary tuberculosis and treatment outcome of patients consulted and treated under program conditions in the littoral region of Cameroon. BMC Pulmonary Medicine 2019;19(1):1-7. DOI: 10.1186/s12890-0180770-x.
23. Dunlap NE, Bass J, Fujiwara P, Hopewell P, Horsburgh CR, Salfinger M, et al. Diagnostic standards and classification of tuberculosis in adults and children. Am J Respir Crit Care Med 2000;161(4l): 1376-1395.

24. Sharma SK, Mohan A, Sharma A, Mitra DK. Miliary tuberculosis: new insights into an old disease. Lancet Infect Dis 2005;5(7):415-430. DOI: 10.1016/S1473-3099(05)70163-8.

25. Schoenfeld DA, Bernard GR. ARDS network. statistical evaluation of ventilator-free days as an efficacy measure in clinical trials of treatments for acute respiratory distress syndrome. Crit Care Med 2002;30(8):1772-1777. DOI: 10.1097/00003246-20020800000016.

26. Horan TC, Andrus M, Dudeck MA. CDC/NHSN surveillance definition of health care-associated infection and criteria for specific types of infections in the acute care setting. Am J Infect Cont 2008;36(5):309332. DOI: 10.1016/j.ajic.2008.03.002.

27. Suetens C, Morales I, Savey A, Palomar M, Hiesmayr M, Lepape A, et al. European surveillance of ICU-acquired infections (HELICS-ICU): methods and main results. J Hosp Infect 2007;65(Suppl 2):171-173. DOI: 10.1016/S0195-6701(07)60038-3.

28. Behr MA, Edelstein PH, Ramakrishnan L. Revisiting the timetable of tuberculosis. BMJ 2018;362:k2738. DOI: 10.1136/bmj.k2738.

29. Theron G, Peter J, Calligaro G, Meldau R, Hanrahan C, Khalfey H, et al. Determinants of PCR performance (Xpert MTB/RIF), including bacterial load and inhibition, for TB diagnosis using specimens from different body compartments. Sci Rep 2014;4(1):5658. DOI: 10.1038/ srep05658.

30. Muthu V, Agarwal R, Dhooria S, Aggarwal AN, Behera D, Sehgal IS. Outcome of critically ill subjects with tuberculosis: systematic review and Meta-analysis. Respir Care Respiratory Care 2018;63(12): 1541-1554. DOI: 10.4187/respcare.06190. 